\title{
ANALISIS PERHITUNGAN PENCATATAN DAN PELAPORAN PAJAK PERTAMBAHAN NILAI ATAS EKSPEDISI ANTAR PULAU PADA \\ PT. TAJUR JAKARTA
}

\author{
Priscilia Joanna Rundengan \\ Jantje Tinangon \\ Inggriani Elim
}

\author{
Fakultas Ekonomi Jurusan Akuntansi \\ Universitas Sam Ratulangi Manado \\ email: rundenganp@yahoo.com
}

\begin{abstract}
ABSTRAK
Pajak Pertambahan Nilai merupakan sumber penerimaan negara yang sangat dominan,di karenakan untuk memenuhi kebutuhan rakyat. Perusahaan sebagai wajib pajak harus melaksanakan kewajiban perpajakannya sesuai dengan ketentuan undang-undang perpajakan yang dinamis dan terus berubah sesuai dengan laju perkembangan perekonomian negara. PT. Tajur Jakarta adalah perusahaan yang berdiri pada tahun 1967 yang beralamat Jl Jati Baru No. 83 merupakan perusahaan ekspedisi yang menggunakan jasa trucking, dan perusahaan yang menghitung, mencatat, dan melaporkan pajak pertambahan nilai pada konsumen pengguna jasa atas barang yang dikenakan pajak pertambahan nilai.Metode dalam Penelitian ini menggunakan metode penelitian deskriptif yaitu berupa studi kasus dan studi pustaka. Studi kasus dilakukan pada PT TAJUR Jakarta sedangkan studi pustaka dilakukan dengan mengumpulkan data-data dari literatur-literatur yang relevan dengan Pajak Pertambahan Nilai. Berdasarkan hasil penelitian yang diperoleh yaitu bahwa perusahaan telah melakukan perhitungan, pencatatan dan pelaporan dengan baik dan sesuai dengan Undang-undang No. 42 tahun 2009 yaitu dengan menggunakan tarif 10\% untuk setiap Jasa Kena Pajak / Barang Kena Pajak, dan juga hasil yang didapat pula bahwa perusahaan telah melakukan penyetoran dan pelaporan pajak dengan menggunakan e-SPT dan disetorkan melalui bank persepsi paling lambat tanggal 15 (lima belas) setelah akhir masa pajak sesuai dengan Undang-Undang Nomor 42 Tahun 2009 tentang Pajak Pertambahan Nilai.
\end{abstract}

Kata Kunci : Pajak Pertambahan Nilai, Perhitungan, Pencatatan, Pelaporan

\begin{abstract}
Value-added tax represent the source of revenue for very dominant state,to fulfill requirement of people. Company as a taxpayer have to carry out their tax liability in accordance with the provisions of the tax laws are dynamic and constantly changing according to the rate of development of country's economics. PT. Tajur Jakarta was established in 1967 which is located in Jl. Jati Baru No. 83 where the main activities of company is a shipping that uses trucking services, and that companies that count, reecord, and report Value Added Tax on the consumers of services on goods subject to Value Added Tax.The method in this research is using descriptive analysis which is describe the case studies and literature. Case studies conducted in PT TAJUR Jakarta while literature conducted by collecting data from the literature relevant to the Value-added tax. Pursuant to result of obtained research from the study,the company calculating, recording and reporting properly and in accordance with the Law No. 42 of 2009, using the rate of $10 \%$ for each taxable service / goods taxable, and also the results obtained also that the company has to deposit and tax reporting using e-SPT return and paid through the bank by the 15th of each month after the end of the tax period in accordance with law No. 42 of 2009 on Value Added Tax.
\end{abstract}

Keyword : Value Added Tax, Calculating, Recording, Reporting 


\section{LATAR BELAKANG}

\section{PENDAHULUAN}

Sebagai salah satu sumber penerimaan negara yang sangat potensial, sektor Pajak merupakan pilihan yang sangat tepat, selain karena jumlahnya yang relatif stabil tetapi juga merupakan cerminan partisipasi aktif masyarakat dalam membiayai pembangunan.

Pajak Pertambahan Nilai (PPN) yang merupakan pajak yang dikenakan atas setiap pertambahan nilai dari barang atau jasa dalam peredarannya dari produsen ke konsumen.Pajak Pertambahan Nilai (PPN) termasuk jenis pajak tidak langsung, maksudnya pajak tersebut disetor oleh pihak lain (pedagang) yang bukan penanggung pajak atau dengan kata lain, penanggung pajak (konsumen akhir) tidak menyetorkan langsung pajak yang ia tanggung. Mekanisme perhitungan pencatatan, penyetoran, dan pelaporan PPN ada pada pihak pedagang atau produsen sehingga muncul istilah Pengusaha Kena Pajak yang disingkat PKP.Berdasarkan Undang-Undang Perpajakan Republik Indonesia Nomor 8 Tahun 1983 sebagaimana yang telah diubah dengan Undang-Undang Nomor 42 Tahun 2009 tentang Pajak Pertambahan Nilai barang dan jasa dan Pajak Penjualan atas Barang Mewah, menyatakan bahwa tarif yang dikenakan pada jasa yaitu sebesar $10 \%$ (sepuluh persen) dari jumlah tagihan.Tarif Pajak Pertambahan Nilai (PPN) yang berlaku atas penyerahan barang kena pajak maupun jasa kena pajak adalah tarif tunggal sehingga mudah dalam pelaksanaannya tidak ada penggolongan dengan tarif yang berbeda.Sistem yang dianut dalam perpajakan Indonesia adalah sistem self assesment. Dalam sistem ini, Wajib Pajak diberikan kepercayaan untuk menghitung, menyetor, dan melaporkan sendiri kewajiban perpajakannya.

PT TAJUR adalah salah satu perusahaan yang bergerak di bidang pelayanan jasa pengiriman barang jalur darat dengan via Trucking dengan tujuan Jakarta-Palembang dengan kuantitas besar.Perusahaan ini hanya bergerak pada Jasa Trucking dan merupakan salah satu perusahaan yang sudah menerapkan pajak pertambahan nilai dalam usahanya, untuk itu perusahaan harus melakukan proses perhitungan, pencatatan dan pelaporan Pajak Pertambahan Nilai. Dan penerapan pajak pertambahan nilai mulai dari perhitungan, pencatatan sampai pelaporan harus dilakukan sesuai dengan undang-undang yang berlaku. Berdasarkan latar belakang, maka penulis merumuskan permasalahan yaitu: Bagaimanakah perhitungan, pencatatan dan pelaporan Pajak Pertambahan Nilai yang dilakukan oleh PT. Tajur Jakarta?

\section{Tujuan Penelitian}

Adapun tujuan penelitian ini adalah untuk menganalisis Perhitungan, Pencatatan dan Pelaporan Pajak Pertambahan Nilai (PPN) Atas Ekspedisi Antar Pulau pada PT.TAJUR.

\section{Pengertian Pajak}

\section{TINJAUAN PUSTAKA}

Pajak adalah iuran rakyat kepada kas negara berdasarkan undang-undang (yang dapat dipaksakan) dengan tiada mendapat jasa timbal balik (kontraprestasi) yang langsung dapat ditunjukkan, dan yang digunakan untuk membayar pengeluaran umum (Prof. Rochmat Soemitro, SH $2007: 1)$.

Pajak adalah iuran kepada negara (yang dapat dipaksakan) yang terutang oleh wajib pajak membayarnya menurut peraturan-peraturan dengan tidak mendapat prestasi kembali, yang langsung dapat ditunjuk yang kegunaannya untuk membiayai pengeluaran-pengeluaran mum berhubungan langsung dengan tugas negara untuk menyelenggarakan pemerintahan (P.J.A Andriani 2007 : 3).

\section{Fungsi Pajak}

Menurut Siti Resmi (2011:3) Fungsi pajak berarti kegunaan atau manfaat dari pajak itu sendiri . Umumnya terdapat 2 fungsi pajak yang dikenal, yaitu :

a. $\quad$ Fungsi Budgetair (Sumber Keuangan Negara) 
Pajak mempunyai fungsi budgetair,artinya pajak merupakan salah satu penerimaan pemerintah untuk membiayai pengeluaran baik rutin maupun pembangunan.Sebagai sumber keuangan negara, pemerintah berupaya memasukkan uang sebanyak-banyaknya untuk kas negara. Upaya tersebut ditempuh dengan cara ekstensifikasi dan intensifikasi pemungutan pajak melalui penyempurnaan peraturan berbagai jenis pajak seperti Pajak Penghasilan (PPh), Pajak Pertambahan Nilai (PPN) dan Pajak Penjualan atas Barang Mewah (PPnBM), Pajak Bumi dan Bangunan (PBB), dan lain-lain.

b. $\quad$ Fungsi Regularend (Pengatur)

Pajak mempunyai fungsi pengatur, artinya pajak sebagai alat untuk mengatur atau melaksanakan kebijkan pemerintah dalam bidang social dan ekonomi, serta mencapai tujuan-tujuan tertentu diluar bidang keuangan

\section{Pajak Pertambahan Nilai (PPN)}

Menurut Waluyo (2011:9) Pajak Pertambahan Nilai dan Pajak Penjualan atas Barang Mewah merupakan Pajak yang dikenakan atas konsumsi di dalam negeri (di dalam Daerah Pabean), baik konsumsi barang maupun konsumsi jasa.

Menurut UU No.42 Tahun 2009, Pajak Pertambahan Nilai (PPN) adalah "Pajak yang dikenakan atas konsumsi barang dan jasa, di dalam daerah pabean yang dikenakan bertingkat disetiap jalur produksi dan distribusi."

\section{Tarif Pajak Pertambahan Nilai}

Menurut Undang-undang Perpajakan (2010:211) Berdasarkan Pasal 7 ayat (1), (2) dan (3) undang-undang no. 42 Tahun 2009, tarif Pajak Pertambahan Nilai

a. Tarif Pajak Pertambahan Nilai sebesar $10 \%$

b. $\quad$ Tarif Pajak Pertambahan Nilai atas ekspor Barang Kena Pajak sebesar $0 \%$.

c. Tarif pajak sebagaimana dimaksud pada ayat (1) dapat diubah menjadi paling rendah $5 \%$ (lima persen) dan paling tinggi $15 \%$ (lima belas persen) yang perubahan tarifnya diatur dengan peraturan pemerintah.

\section{CARA MENGHITUNG PAJAK PERTAMBAHAN NILAI}

Menurut Waluyo (2011:21) Cara menghitung Pajak Pertambahan Nilai yang terutang adalah dengan mengkalikan Tarif Pajak Pertambahan Nilai ( $10 \%$ atau $0 \%$ untuk ekspor Barang Kena Pajak) dengan Dasar Pengenaan Pajak.

\section{PPN yang Terutang = Tarif PPN $\times$ Dasar Pengenaan Pajak}

\section{PENCATATAN}

Menurut Pasal 28 ayat (9) UU KUP menyatakan pencatatan adalah pengumpulan data secara teratur tentang peredaran atau penerimaan bruto dan/atau penghasilan bruto sebagai dasar untuk menghitung jumlah pajak yang terutang, penghasilan yang dikenakan pajak yang bersifat final.

Pencatatan atas peredaran bruto juga menjadi dasar penghitungan PPN bagi PKP yang menghitung penghasilan neto mempergunakan norma penghitungan (peredaran bruto menjadi dasar penghitungan Pajak Keluaran dan Jumlah Pajak Masukan yang dapat dikreditkan).

Menurut waluyo (2012;332) Dalam akuntansi komersial tidak mengatur tersendiri perilaku akuntansi khusus untuk PPN maupun PPnBM, PSAK hanya mengatur Akuntansi Pajak Penghasilan.

Namun demikian baik dalam akuntansi komersial maupun dalam akuntansi pajak terdapat persamaan dalam melakukan pencatatan yang harus dipersiapkan antara lain :

a. Akun Pajak Masukan 
Untuk mencatat besarnya Pajak Masukan yang dibayar atau dipungut atas terjadinya transaksi pembelian

b. Akun Pajak Keluaran

Pada akun ini untuk mencatat Pajak Keluaran yang dipugut atau disetorkan ke kas negara atas transaksi.

\section{PELAPORAN PAJAK}

Menurut (Rudi \& Wirawan, 2010:12) Kewajiban WP setelah melakukan penyetoran pajak adalah melaporkan seluruh penghitungan dan penyetoran pajak tersebut ke KPP tempat WP tersebut terdaftar dengan menggunakan formulir SPT. Pelaporan tersebut ada yang dilakukan berdasarkan bulan (Masa Pajak) dan juga tahunan. Menurut (Rudi \& Wirawan, 2010:56) Pasal 1 angka 11 UU KUP menegaskan bahwa SPT adalah surat yang oleh WP digunakan untuk melaporkan penghitungan dan pembayaran pajak, objek pajak dan/atau bukan objek pajak, dan/atau harta dan kewajiban sesuai dengan ketentuan peraturan perudang-undangan perpajakan.

\section{Jenis Penelitian}

\section{METODE PENELITIAN}

Penelitian ini menggunakan metode penelitian deskriptif yaitu berupa studi kasus dan studi pustaka. Studi kasus dilakukan pada PT TAJUR Jakarta sedangkan studi pustaka dilakukan dengan mengumpulkan data-data dari literatur-literatur yang relevan dengan Pajak Pertambahan Nilai.

Penelitian ini menggunakan metode Perhitungan, Pencatatan, dan Pelaporan Pajak Pertambahan Nilai pada PT Tajur dengan peraturan Undang-Undang perpajakan yang ada, sebagaimana terdapat dalam peraturan pemerintah.

\section{Lokasi Penelitian dan Waktu Penelitian}

Pemilihan lokasi yang dilakukan pada kantor PT TAJUR Jakarta yang beralamat di Tanah Abang Jl Jati Baru No.83 Jakarta Pusat. Penelitian ini dilaksanakan pada bulan Oktober - November.

\section{Prosedur Penelitian}

Prosedur yang dilakukan dalam penelitian ini adalah sebagai berikut:

1. Menentukan judul dan merumuskan masalah.

2. Menelaah tinjauan pustaka / literatur yang timbul dengan peneliti.

3. Mengumpulkan data sesuai permasalahan yang diangkat.

4. Pengumpulan data melalui wawancara terhadap pihak-pihak yang terkait serta pengambilan data-data pada Kantor PT TAJUR untuk mengetahui bagaimana analisis penghitungan, pencatatan dan pelaporan pajak pertambahan nilai.

5. Mengolah data dan menginterpretasikan hasil pengolahan data.

6. Menarik kesimpulan dan memberikan saran yang dianggap perlu sebagai perbaikan dalam masalah yang ada.

\section{Metode Pengumpulan Data}

\section{Jenis Data}

1. Data kuantitatif

Menurut Fathoni (2011: 37) menyatakan data kuantitatif merupakan data yang disajikan dalam bentuk angka - angka dan tabel.. Dalam penelitian ini yakni data Pajak Keluaran dan Pajak Masukan PT TAJUR JAKARTA.

2. Data kualitatif

Menurut Fathoni (2011: 37) menyatakan data kualitatif adalah data yang disajikan dalam bentuk uraian deskriptif mengenai gambaran umum dan sebagainya. 
Jenis data yang digunakan dalam penelitian ini adalah jenis data kualitatif berupa profil perusahaan PT TAJUR, kegiatan operasional dan data kepustakaan.

\section{Sumber Data}

1. Data Primer

Menurut Fathoni (2011:30) Data primer merupakan data yang diperoleh langsung dari perusahaan atau tempat penelitian. Dalam penelitian ini yakni saat wawancara dengan karyawan perusahaan tentang pengambilan data sejarah perusahaan, struktur organisasi, pembagian tugas kerja, kinerja dari para pekerja, dan lain sebagainya.

2. Data Sekunder

Fathoni (2011: 38) menyatakan data sekunder merupakan data yang diperoleh dari literatur - literatur serta tulisan - tulisan yang berhubungan dengan penelitian ini.Dalam penelitian ini data sekunder yang digunakan yakni PPN Keluaran dan PPN Masukan serta laporan Pajak Pertambahan Nilai (SPT Masa PPN) dari perusahaan periode 2012.

\section{Teknik Pengumpulan Data}

Teknik atau cara yang digunakan dalam pengumpulan data adalah sebagai berikut:

1. Teknik Observasi

Teknik observasi merupakan pengumpulan data yang dilakukan dengan pengamatan langsung terhadap dokumen-dokumen yang berhubungan dengan penghitungan, pencatatan dan pelaporan pajak pertambahan nilai.

2. Teknik Wawancara

Teknik wawancara dilakukan dengan wawancara secara langsung dengan pihak-pihak yang terkait yang dibutuhkan. Yakni Pimpinan perusahaan dan karyawan perusahaan.

3. Teknik Dokumentasi

Yaitu metode pengumpulan data dengan cara mempelajari dokumen, bukti-bukti atau catatan yang berhubungan dengan objek yang diteliti. Penelitian ditujukan pada dokumendokumen yang berhubungan dengan data yang diperlukan. Pengumpulan data dokumentasi menggunakan alat tulis manual maupun elektronik.

\section{Metode Analisis}

Metode analisis yang digunakan dalam penelitian ini adalah analisis deskriptif yaitu suatu metode yang dilakukan dengan cara mengumpulkan, menyajikan, serta menganalisis data sehingga diperoleh gambaran yang cukup jelas tentang masalah yang dihadapi, kemudian ditarik suatu kesimpulan mengenai analisis perhitungan,pencatatan dan pelaporan pajak pertambahan nilai apakah sesuai dengan peraturan Undang-Undang perpajakan yang ada, sebagaimana terdapat dalam peraturan pemerintah.

\section{HASIL PENELITIAN DAN PEMBAHASAN}

\section{HASIL PENELITIAN}

PT. Tajur merupakan Pengusaha Kena Pajak dengan Nomor Pokok Wajib Pajak (NPWP) 01.102.620.0.307.000. PT. Tajur resmi berdiri sebagai badan usaha yang otonom pada tahun1973. Hingga saat ini PT. Tajur memiliki 3 kantor yang pusatnya berada di palembang dan yang duanya lagi berada di Tanah Abang Jalan Jati Baru dan Cikupa.

Objek yang dikenakan Pajak Pertambahan Nilai pada PT. Tajur yaitu berupa Jasa angkutan yang mengangkut barang dari tempat pengiriman ke tempat tujuan berdasarkan Berat Barang, Kubikasi, dan besarnya mobil angkutan yang dipakai. 
Sebagai Pengusaha Kena Pajak PT. Tajur membuat / menerbitkan faktur pajak untuk setiap penyerahanJasa Kena Pajak yang digunakan sebagai bukti pemungutan pajak yang selalu disertakan dalam setiap penyerahan Jasa Kena Pajak.

\section{Analisis Perhitungan Pajak Pertambahan Nilai}

PT. TAJUR menghitung Pajak Pertambahan Nilai yang harus disetor serta PPN yang harus dipungut adalah berdasarkan rumus :

\section{Pajak Pertambahan Nilai = Dasar Pengenaan Pajak X Tarif Pajak 10\%}

Berikut ini contoh perhitungan Pajak Pertambahan Nilai yang dilakukan PT.TAJUR :

PT. TAJUR yang merupakan perusahaan yang bergerak dalam jasa angkutan menerima Jasa Angkutan dari PT. SHARP INDONESIA untuk mengangkut barang-barang elektronik dengan biaya Jasa Transportasi yang dibayarkan PT Sharp dihitung dengan Kubikasi.

\section{Perhitungan Pajak Keluaran :}

$\begin{array}{lll}\text { DPP } & =\operatorname{Rp} 22.704 .750 \\ \text { Pajak Keluaran } 10 \% & =\operatorname{Rp} & 2.270 .475\end{array}$

Berikut akan disediakan penjabaran secara singkat mengenai Pajak Keluaran PT. Tajur Tahun 2012:

Tabel 4.6.1.1

Pajak Keluaran Masa Tahun 2012

\begin{tabular}{|c|c|c|}
\hline \multirow{2}{*}{ Masa Pajak } & \multicolumn{2}{|c|}{ Penjualan } \\
\hline & $\mathrm{DPP}(\mathrm{Rp})$ & PPN (Rp) \\
\hline Januari & Rp. 1.054.409.910 & Rp. 105.440.991 \\
\hline Februari & Rp. 1.281.930.120 & Rp. 128.193.012 \\
\hline Maret & Rp. 1.223.892.970 & Rp. 122.389.297 \\
\hline April & Rp. 1.080.930.320 & Rp. 108.093.032 \\
\hline Mei & Rp. 1.210.523.310 & Rp. 121.052.331 \\
\hline Juni & Rp. 1.079.806.860 & Rp. 107.980.686 \\
\hline Juli & Rp. 1.085.897.820 & Rp. 108.589.782 \\
\hline Agustus & Rp. 1.032.147.070 & Rp. 103.214.707 \\
\hline September & Rp. 1.016.643.800 & Rp. 101.664.380 \\
\hline Oktober & Rp. 1.321.637.780 & Rp. 132.163.778 \\
\hline November & Rp. 1.166.310.810 & Rp. 116.631.081 \\
\hline Desember & Rp. 972.481.670 & Rp. 97.248.167 \\
\hline TOTAL & Rp. 13.526.612.440 & Rp. 1.352.697.244 \\
\hline
\end{tabular}

Sumber : Data Olahan

Berdasarkan tabel 4.6.1 Dapat dilihat bahwa besarnya Penjualan yang diperoleh perusahaan selama tahun 2012 dengan Dasar Pengenaan Pajak sebesar Rp. 13.526.612.440, menghasilkan Pajak Keluaran sebesar Rp. 1.352.697.244.

\section{Perhitungan Pajak Masukan:}

PT. TAJUR yang merupakan perusahaan yang bergerak dalam jasa angkutan Membeli mobil dari PT. Istana Kebon Jeruk dengan Dasar Pengenaan Pajak Rp. 140.244.136, perhitungan pajak masukan PT. Tajur adalah:

$$
\begin{array}{ll}
\mathrm{DPP} & =\text { Rp. 140.244.136 } \\
\text { Pajak Masukan 10\% } & =\text { Rp 14.024.414. }
\end{array}
$$


Berikut akan disediakan penjabaran secara singkat mengenai Pajak Masukan PT. Tajur Tahun 2012:

Tabel 4.6.1.2

Pajak Masukan Masa Tahun 2012

\begin{tabular}{|c|c|c|c|}
\hline \multirow{2}{*}{ Masa Pajak } & \multicolumn{3}{|c|}{ Pembelian } \\
\hline & $\mathrm{DPP}(\mathrm{Rp})$ & PPN (Rp) & Jumlah (Rp) \\
\hline \multicolumn{4}{|l|}{ Januari } \\
\hline \multicolumn{4}{|l|}{ Februari } \\
\hline \multicolumn{4}{|l|}{ Maret } \\
\hline \multicolumn{4}{|l|}{ April } \\
\hline \multicolumn{4}{|l|}{ Mei } \\
\hline \multicolumn{4}{|l|}{ Juni } \\
\hline \multicolumn{4}{|l|}{ Juli } \\
\hline Agustus & Rp. 236.725.909 & Rp. 23.672.589 & Rp. 260.398 .498 \\
\hline September & Rp. 1.140.909.091 & Rp. 114.090.905 & Rp. 1.254.999.996 \\
\hline Oktober & Rp. 327.315.454 & Rp. 32.731 .545 & Rp. 360.046.999 \\
\hline \multicolumn{4}{|l|}{ November } \\
\hline \multicolumn{4}{|l|}{ Desember } \\
\hline TOTAL & Rp. 1.704.950.454 & Rp. 170.495.039 & \begin{tabular}{|l|l|} 
Rp. 1.875 .445 .493 \\
\end{tabular} \\
\hline
\end{tabular}

Sumber: Data Olahan

Berdasarkan tabel 4.6.1.2 Dapat dilihat bahwa besarnya Pembelian yang dilakukan oleh PT. Tajur selama tahun 2012 dengan Dasar Pengenaan Pajak sebesar Rp. 1.704.950.454, menghasilkan Pajak Masukan sebesar Rp. 170.495.045, dan total pembelian pada tahun 2012 adalah sebesar Rp. 1.875.445.493.

\section{Pajak Pertambahan Nilai Lebih Bayar / Kurang Bayar}

Perhitungan besarnya Pajak Pertambahan Nilai yang Lebih Bayar atau yang Kurang Bayar dapat dihitung berdasarkan data-data Pajak Keluaran dan Pajak Masukan yang telah dijabarkan penulis sebelumnya.

Berikut akan disediakan penjabaran secara singkat mengenai besarnya Pajak Pertambahan Nilai Lebih Bayar / Kurang Bayar PT. Tajur pada tahun 2012:

Tabel 4.6.2.

Perhitungan Pajak Pertambahan Nilai (PPN) PT. Tajur Selama Tahun 2012

\begin{tabular}{|c|c|c|c|c|c|}
\hline $\begin{array}{l}\text { Masa } \\
\text { Pajak }\end{array}$ & $\begin{array}{c}\text { Pajak } \\
\text { Keluaran } \\
(\mathrm{Rp})\end{array}$ & $\begin{array}{c}\text { Pajak Masukan } \\
\text { (Rp) }\end{array}$ & Kompensasi & $\begin{array}{c}\text { Kurang / } \\
\text { (Lebih) Bayar } \\
\text { (Rp) }\end{array}$ & $\begin{array}{c}\text { Dikompensasikan } \\
\text { Ke Bulan }\end{array}$ \\
\hline Januari & Rp. 105.440.991 & & - & Rp. 105.440.991 & - \\
\hline Februari & Rp. 128.193.012 & & - & Rp. 128.193.012 & - \\
\hline Maret & Rp. 122.389.297 & & - & Rp. 122.389.297 & - \\
\hline April & Rp. 108.093.032 & & - & Rp. 108.093.032 & - \\
\hline Mei & Rp. 121.052.331 & & - & Rp. 121.052.331 & - \\
\hline Juni & Rp. 107.980.686 & & - & Rp. 107.980.686 & - \\
\hline Juli & Rp. 108.589.782 & & - & Rp. 108.589.782 & - \\
\hline Agustus & Rp. 103.214.707 & Rp. 23.672.589 & - & Rp. 79.542.118 & - \\
\hline September & Rp. 101.664.380 & Rp. 114.090.905 & - & Rp. 12.426.525 & - \\
\hline Oktober & Rp. 132.163.778 & Rp. 285.321.702 & - & $(\operatorname{Rp} 153.157 .925)$ & November 2012 \\
\hline November & Rp. 116.631.081 & & Rp. 153.157.925 & (Rp.36.526.844) & Desember 2012 \\
\hline Desember & Rp. 97.248.167 & & Rp 36.526.844 & Rp. 60.721 .323 & - \\
\hline TOTAL & Rp. 1.352.697.244 & Rp. 423.085.196 & Rp. 189.684.769 & Rp. 954.429.097 & - \\
\hline
\end{tabular}

Sumber : Data Olahan 


\section{Analisis Pencatatan Pajak Pertambahan Nilai}

Dari setiap transaksi penjualan yang dilakukan, perusahaan akan membuat jurnal atas Pajak Keluaran yang dipungut perusahaan. Pencatatan atas penerimaan hasil penjualan jasa tunai dilakukan dengan mendebit perkiraan kas dan mengkredit perkiraan penjualan jasa dan Pajak Keluarannya.

\section{Pencatatan Pajak Keluaran}

Selama bulan desember 2012 PT. Tajur menjual Jasa Kena Pajak kepada PT. Sharp Electronics Indonesia dengan dasar pengenaan pajak sebesar Rp. 972.481.670, sehingga Pajak Keluaran yang dipungut sebesar Rp. 97.248.167. perusahaan akan mencatat jurnal sebagai berikut: Kas Rp. 1.069.729.837

$\begin{array}{llr}\text { Penjualan } & \text { Rp. } & 972.481 .670 \\ \text { PPN Keluaran } & \text { Rp. } & 97.248 .167\end{array}$

\section{Pencatatan Pajak Masukan}

Contoh: Selama bulan juni 2012 PT. Tajur membeli Barang Kena Pajak kepada PT. Istana Kebun Jeruk dengan Dasar Pengenaan Pajak sebesar Rp. 140.244.136, sehingga Pajak Keluaran yang dipungut sebesar Rp. 14.024.414. perusahaan akan mencatat jurnal sebagai berikut :

$\begin{array}{ll}\text { Pembelian } & \text { Rp. } 140.244 .136 \\ \text { PPN Masukan } & \text { Rp. } 14.024 .414\end{array}$

Kas Rp. 154.268 .550

\section{Pencatatan Pembayaran Pajak Pertambahan Nilai Kepada Kas Negara.}

Seluruh Pajak Keluaran dan Pajak Masukan diperhitungkan dalam SPT Masa PPN. Jika Pajak Keluaran lebih besar dari Pajak Masukan maka Pengusaha Kena Pajak masih harus membayar selisihnya kepada kas negara. Berdasarkan contoh sebelumnya, dengan asusmsi tidak ada transaksi lain, maka jurnal perhitungan kurang bayar adalah :

PPN Keluaran

Rp. $\quad 97.248 .167$

$\begin{array}{ll}\text { PPN Masukan } & \text { Rp. } 36.562 .844 \\ \text { Kas } & \text { Rp. } 60.721 .323\end{array}$

\section{Analisis Penyetoran dan Pelaporan Pajak Pertambahan Nilai}

PT. TAJUR wajib melakukan penyetoran Pajak Pertambahan Nilai yang Kurang Bayar dengan menggunakan Surat Setoran Pajak kepada Kantor Pelayanan Pajak tempat Wajib Pajak dikukuhkan sebagai Pengusaha Kena Pajak.

Surat Setoran Pajak ini dibuat dalam rangkap 5 (lima) yang terdiri dari:

- Lembar ke-1 : Untuk arsip PT. TAJUR

- Lembar ke-2 :Untuk Kantor Pelayanan Pajak melalui Kantor Perbendaharaan Kas Negara (KPKN).

- Lembarke-3 :Untuk PT. TAJUR yang akan dilampirkan pada Surat Pemberitahuan Masa Pajak Pertambahan Nilai.

- Lembar ke-4 : :Untuk arsip Kantor Penerimaan Pembayaran

- Lembar ke-5 :Untuk arsip Pemungut/Pihak lain.

Menurut Undang-Undang No.42 tahun 2009 , penyetoran Pajak Pertambahan Nilai paling lambat penyetoran dilakukan akhir bulan berikutnya setelah Masa Pajak berakhir dan sebelum Surat 
Pemberitahuan Masa disampaikan. Namun apabila perusahaan tidak melakukan pembayaran ataupun penyetoran Pajak Pertambahan Nilai sesuai dengan peraturan yang berlaku.

Berikut penjabaran mengenai penyetoran Pajak Pertambahan Nilai yang dilakukakn oleh PT. TAJUR apakah sudah sesuai atau tidak dengan Undang-Undang Pajak Pertambahan Nilai No.42 Tahun 2009 yang berlaku untuk Masa pajak periode Januari s/d Desember 2012 :

TABEL 4.6.4

Penyetoran Pajak Pertambahan Nilai (PPN) PT.TAJUR Tahun 2012

\begin{tabular}{|c|c|c|}
\hline Masa Pajak & Tanggal Setor & $\begin{array}{c}\text { Keterangan Sesuai / tidak Sesuai dengan } \\
\text { UU PPN No. 42 Tahun 2009 }\end{array}$ \\
\hline Januari & 27 Februari 2012 & Sesuai \\
\hline Februari & 28 Maret 2012 & Sesuai \\
\hline Maret & 23 April 2012 & Sesuai \\
\hline April & 22 Mei 2012 & Sesuai \\
\hline Mei & 26 Juni 2012 & Sesuai \\
\hline Juni & 19 Juli 2012 & Sesuai \\
\hline Juli & 27 Agustus 2012 & Sesuai \\
\hline Agustus & 26 September 2012 & Sesuai \\
\hline September & 22 Oktober 2012 & Tidak ada Setoran / Lebih Bayar \\
\hline Oktober & 26 November 2012 & Sesuai \\
\hline November & 10 Desember 2012 & Tidak ada Setoran / Bebih Bayar \\
\hline Desember & 23 Januari 2013 & Sesuar \\
\hline Datahan & &
\end{tabular}

Sumber : Data Olahan

Berdasarkan tabel 4.6.4 dapat dilihat bahwa selama tahun 2012 PT. Tajur telah menyetorkan PPN melalui bank persepsi yang ditunjuk yaitu Bank Permata sesuai dengan UU No. 42 Tahun 2009, tidak mengalami keterlambatan penyetoran.

\section{Pelaporan SPT Masa PPN}

Berdasarkan Undang-Undang No. 18 Tahun 2000 dan telah diubah dengan Undang-Undang No. 42 Tahun 2009 tentang pelaporan Pajak Pertambahan Nilai paling lambat akhir bulan berikutnya setelah berakhirnya Masa Pajak. Surat Pemberitahuan Masa Pajak Pertambahan Nilai disampaikan oleh PT. Tajur di Kantor Pelayanan Pajak tempat perusahaan dikukuhkan sebagai Pengusaha Kena Pajak. Apabila perusahaan terlambat dalam melakukan pelaporan Surat Pemberitahuan Masa Pajak Pertambahan Nilai, maka perusahaan akan dikenakan sanksi sebesar Rp. 500.000,- (Lima Ratus Ribu Rupiah) sesuai dengan Undang-Undang Nomor 28

PT. Tajur dalam hal penyampaian Surat Pemberitahuan Masa PPN dilakukan secara elektronik (e. Filing).

Berikut ini akan diberikan penjabaran mengenai apakah PT. Tajur telah melaporkan Surat Pembetitahuan Masa Pajak Pertambahan Nilai sesuaidengan Undang - Undang No. 42 Tahun 2009 atau tidak sesuai untuk masa pajak 2012. 
Tabel 4.6.5

Pelaporan SPT MASA PPN PT. Tajur Periode Januari s/d desember 2012

\begin{tabular}{|c|c|c|c|}
\hline Masa Pajak & $\begin{array}{c}\text { Kurang / (Lebih) } \\
\text { Bayar (Rp) }\end{array}$ & Tanggal Lapor & $\begin{array}{c}\text { Keterangan Sesuai / } \\
\text { tidak Sesuai dengan } \\
\text { UU PPN No. 42 } \\
\text { Tahun 2009 }\end{array}$ \\
\hline Januari & Rp. 105.440.991 & 27 Februari 2012 & Sesuai \\
\hline Februari & Rp. 128.193.012 & 28 Maret 2012 & Sesuai \\
\hline Maret & Rp. 122.389.297 & 23 April 2012 & Sesuai \\
\hline April & Rp. 108.093.032 & 22 Mei 2012 & Sesuai \\
\hline Mei & Rp. 121.052.331 & 26 Juni 2012 & Sesuai \\
\hline Juni & Rp. 107.980.686 & 19 Juli 2012 & Sesuai \\
\hline Juli & Rp. 108.589.782 & 27 Agustus 2012 & Sesuai \\
\hline Agustus & Rp. 79.542.118 & 26 September 2012 & Sesuai \\
\hline September & (Rp. 12.426.525) & 22 Oktober 2012 & Sesuai \\
\hline Oktober & (Rp.153.157.925) & 26 November 2012 & Sesuai \\
\hline November & (Rp. 36.526.844) & 10 Desember 2012 & Sesuai \\
\hline Desember & Rp. 60.721.323 & 23 Januari 2013 & Sesuai \\
\hline
\end{tabular}

Sumber : Data Olahan

Berdasarkan tabel 4.6.5 dapat dilihat bahwa selama tahun 2012 PT. Tajur telah melaporkan SPT Masa PPN pada Kantor Pelayanan Pajak sesuai dengan UU No. 42 Tahun 2009, tidak mengalami keterlambatan pelaporan.

\section{Pembahasan}

Berdasarkan hasil penelitian yang dilakukan pada PT. Tajur mengenai Analisis Perhitungan, Pencatatan dan Pelaporan Pajak Pertambahan Nilai sudah sesuai dengan undang-undang mengenai Pajak Pertambahan Nilai yang berlaku di Indonesia.

Berdasarkan Undang-undang No. 42 tahun 2009 Pajak Keluaran adalah Pajak Pertambahan Nilai terutang yang wajib dipungut oleh Pengusaha Kena Pajak yang melakukan penyerahan Barang Kena Pajak, penyerahan Jasa Kena Pajak, ekspor Barang Kena Pajak berwujud, ekspor Barang Kena Pajak tidak berwujud, dan/atau ekspor Jasa Kena Pajak. Pajak Keluaran yang dipungut oleh perusahaan berasal dari PPN atas penyerahan Jasa Kena Pajak. Penyerahan Jasa Kena Pajak dilakukan oleh PT. Tajur dalam bentuk penyediaan akses pengiriman barang yang digolongkan sebagai penyerahan Jasa Kena Pajak karena memenuhi syarat yang ditetapkan Undang-undang PPN.

Pada tahun 2012 jumlah pendapatan jasa pengiriman barang sebesar Rp. 13.526.612.440, hal ini berarti menunjukan bahwa total Pajak Keluaran yang harus dibayar PT. Tajur adalah sebesar (10\% x Rp. 13.526.612.440) = Rp. 1.352.661.244, Jumlah pendapatan sudah sama dengan jumlah Pajak Keluaran yang harus dibayar yang tertera dalam SPT masa PPN yaitu sebesar Rp. 1.352.661.244.

Tarif Pajak Pertambahan Nilai adalah 10\% (sepuluh persen) sesuai dengan ketetapan dalam UU No. 42 tahun 2009, namun berdasarkan Keputusan Menteri Keuangan No. 567/KMK. 04/2000 dalam pasal 1 dan 2 tarif pajak yang harus dipungut PT. Tajur adalah sebesar 10\% (sepuluh persen) dari jumlah pendapatan atau penjualan Jasa Kena Pajak yang diperoleh. Dan berdasarkan hasil penelitian perusahaan telah melakukan perhitungan dan pemungutan Pajak Pertambahan Nilai sesuai dengan perundang-undangan yang berlaku.

Berdasarkan peraturan Dirjen Pajak yaitu PER-11/PJ/2013 tentang bentuk, isi, dan tata cara pengisian dan penyampaian SPT Masa PPN dan PER-21/PJ/2013 tentang tata cara penerimaan dan pengelolaan SPT Masa PPN, Dirjen Pajak tidak lagi mengijinkan PKP badan untuk melaporkan SPT Masa secara Hard Copy (Manual), kalau dalam peraturan-peraturan sebelumnya PKP badan masih diberikan pilihan untuk memilih melaporkan Surat Pemberitahuan Pajak Masa PPN melalui data 
elektronik atau hard copy asalkan jumlah transaksinya tidak melebihi 25 lembar, maka terhitung mulai masa juni 2013 pilihan itu sudah tertutup. Semua PKP badan harus melaporkan SPT Masa PPN menggunakan e-SPT (electronik-SPT).

PT. Tajur telah melakukan penyetoran dan pelaporan Pajak Pertambahan Nilai melalui e-SPT dan dilaporkan kepada Kantor Pelayanan Pajak setempat dan di setorkan pada Kantor Bank yang ditunjuk yaitu Bank Permata.Berdasarkan Undang-undang No. 42 tahun 2009, pelaporan Pajak Pertambahan Nilai paling lambat akhir bulan berikutnya setelah berakhirnya masa pajak. Dalam hal pelaporan Pajak Pertambahan Nilai PT. Tajur sudah melakukan pelaporan SPT Masa PPN pada Kantor Pelayanan Pajak sesuai dengan ketentuan perundang-undangan yang berlaku.

\section{Kesimpulan}

\section{PENUTUP}

Berdasarkan dari hasil penelitian dan data yang diperoleh pada PT. Tajur, maka penulis dapat mengambil kesimpulan bahwa :

1. Dalam melaksanakan Perhitungan Pajak Pertambahan Nilai atas Barang Kena Pajak / Jasa Kena Pajak, PT. Tajur telah mengikuti pedoman sesuai dengan Undang-undang No. 42 tahun 2009 yaitu dengan menggunakan tarif 10\% untuk setiap Jasa Kena Pajak / Barang Kena Pajak.

2. PT.TAJUR Dalam melaksanakan Pencatatan Pajak Pertambahan Nilai atas Barang Kena Pajak / Jasa Kena Pajak, PT. Tajur telah mengikuti pedoman Undang-undang PPN yang berlaku

3. PT.TAJUR adalah perusahaan jasa yang telah melakukan penyetoran dan pelaporan pajak dengan menggunakan e-SPT dan disetorkan melalui bank persepsi paling lambat tanggal 15 (lima belas) setelah akhir masa pajak sesuai dengan Undang-Undang Nomor 42 Tahun 2009 tentang Pajak Pertambahan Nilai.

\section{Saran}

Berdasarkan hasil evaluasi dan pembahasan pada PT. TAJUR maka penulis memberikan saran-saran yang dapat dijadikan bahan pertimbangan dan masukan :

1. PT. Tajur harus selalu siap dalam menghadapi perubahan-perubahan peraturan perpajakan sehingga tidak terjadi permasalahan di kemudian hari mengenai Pajak Pertambahan Nilai dan harus selalu up to date mengenai perkembangan ketentuan perpajakan yang berlaku, mengingat peraturan perundang-undangan perpajakan yang berlaku di Indonesia sering mengalami perubahan sesuai dengan situasi dan kondisi mengikuti perkembangan sosial dan ekonomi.penyetoran dan pelaporan yang telah sesuai dengan UU No. 42 Tahun 2009 tentang PPN, maka perusahaan harus terus mempertahankan kepatuhan terhadap peraturan dan sebisa mungkin menghindari kelalaian manusia.

2. Dalam penyimpanan Faktur Pajak dan data-data mengenai perpajakan, kiranya PT. Tajur bisa mengelola dan menyimpannya dengan baik agar dalam perhitungan pajak dikemudian hari bisa lebih mudah, dan apabila peneliti selanjutnya melakukan penelitian pada PT. Tajur datadata yang dibutuhkan bisa diberikan dengan cepat dan lengkap.

3. PT. Tajur sebaiknya mempekerjakan seseorang yang ahli dalam bidang perpajakan sehingga fokus perpajakan bisa di kelola lebih baik, sehingga meminimalisir kemungkinan terjadinya kesalahan perhitungan atau pencatatan serta pelaporan pajak dan bisa menghindari sanksi di kemudian hari. 


\section{DAFTAR PUSTAKA}

Fakultas Ekonomi Universitas Sam Ratulangi, 2013. Buku Panduan Penulisan Skripsi Dan Artikel. Manado

Fathoni, Abdurrahmat. 2011. Metodologi Penelitian \& Teknik Penyusunan Skripsi. PT Rineka Cipta. Jakarta.

Fitriandi, P., Aryanto Y., \& Puji Priyono, A., 2010, “Kompilasi Undang-undang Perpajakan”, Salemba Empat, Jakarta

Irwansyah Lubis. Gustian Djuanda, Ardiansyah Lubis. 2010, "Review Pajak Orang Pribadi Dan Orang Asing”, Salemba Empat, Jakarta.

Kuncoro, Mudrajad. 2009. Metode Riset Untuk Bisnis dan Ekonomi. Edisi 3. Erlangga Jogjakarta. Mardiasmo. 2009 , Perpajakan. Jakarta, Andi.

Republik Indonesia, UU No. 42 Tahun 2009., "Tentang Pajak Pertambahan Nilai

Dan Jasa Dan Pajak Penjualan Atas Barang Mewah"

Rudy Suhartono, Wirawan B. Ilyas. 2010, “Panduan Komprehensif dan Praktis

Ketentuan Umum dan Tata Cara Perpajakan (KUP)”, Salemba Empat, Jakarta

Siti Resmi. 2011, "Perpajakan Teori Dan Kasus”, Salemba Empat, Jakarta

Siti Resmi. 2012, "Perpajakan Teori Dan Kasus", Salemba Empat, Jakarta

Waluyo.2009, “Akuntansi Pajak”. Jakarta, Salemba Empat

Waluyo.2012, “Akuntansi Pajak”. Jakarta, Salemba Empat

Yamin, Mohammad. 2012. "Pajak Pertambahan Nilai Jilid 1", Graha Ilmu, Yogyakarta 